\title{
Eprosartan Mesylate
}

National Cancer Institute

\section{Source}

National Cancer Institute. Eprosartan Mesylate. NCI Thesaurus. Code C47515.

The mesylate salt form of eprosartan, a non-biphenyl, non-tetrazole, nonpeptide

angiotensin II antag onist with antihypertensive activity. Eprosartan mesylate antagonizes

angiotensin II type I receptors in tissues such as vascular smooth muscle and the adrenal gland. This prevents ang iotensin II-induced vasoconstriction and prevents angiotensin IImediated stimulation of aldosterone secretion by the adrenal cortex, which decreases the excretion of sodium and water and increases the excretion of potassium. 